Additional Perspectives articles for Influenza: The Cutting Edge book collection are available at http://perspectivesinmedicine.cshlp.org/cgi/collection/influenza_the_cutting_edge.

\title{
Live Attenuated Cold-Adapted Influenza Vaccines
}

\author{
Kanta Subbarao \\ WHO Collaborating Centre for Reference and Research on Influenza and Department of Microbiology \\ and Immunology, University of Melbourne at The Peter Doherty Institute for Infection and Immunity, \\ Melbourne, Victoria 3000, Australia \\ Correspondence: kanta.subbarao@influenzacentre.org
}

Live attenuated, cold-adapted influenza vaccines exhibit several desirable characteristics, including the induction of systemic, mucosal, and cell-mediated immunity resulting in breadth of protection, ease of administration, and yield. Seasonal live attenuated influenza vaccines (LAIVs) were developed in the United States and Russia and have been used in several countries. In the last decade, following the incorporation of the 2009 pandemic H1 N1 strain, the performance of both LAIVs has been variable and the U.S.-backbone LAIV was less effective than the corresponding inactivated influenza vaccines. The cause appears to be reduced replicative fitness of some $\mathrm{H} 1 \mathrm{~N} 1 \mathrm{pdm} 09$ viruses, indicating a need for careful selection of strains included in multivalent LAIV formulations. Assays are now being implemented to select optimal strains. An improved understanding of the determinants of replicative fitness of vaccine strains and of vaccine effectiveness of LAIVs is needed for public health systems to take full advantage of these valuable vaccines.

\begin{abstract}
$A^{\text {lthough parenterally administered inactivat- }}$ A ed influenza vaccines induce a protective serum antibody response, there has been and continues to be an interest in live attenuated influenza vaccines because they offer the additional benefits of inducing mucosal and cell-mediated immunity, which confer greater breadth of protection against antigenic variant influenza viruses (Belshe et al. 2000a; Mendelman et al. 2004). Vaccine viruses bearing temperaturesensitive (ts) mutations were of particular interest because the temperature in the nasal passages tends to be a few degrees cooler than the core body temperature of the lower respiratory tract. Therefore, a ts live influenza virus vaccine ad-
\end{abstract}

ministered intranasally would replicate in the nasal mucosa and induce immunity but would be attenuated because of restricted ability to replicate in the lungs (Murphy and Coelingh 2002). The first licensed live attenuated influenza vaccines combined ts and genetic stability in coldadapted (ca) vaccines and were developed in the United States and Russia in the 1970s (Maassab 1967, 1969; Ghendon et al. 1984; Kendal 1997). In both cases, the hemagglutinin (HA) and neuraminidase (NA) gene segments of the vaccine viruses are derived from circulating influenza viruses, because these two proteins are the targets of the protective immune response. The remaining six gene segments are derived from

Editors: Gabriele Neumann and Yoshihiro Kawaoka

Additional Perspectives on Influenza: The Cutting Edge available at www.perspectivesinmedicine.org

Copyright (C) 2021 Cold Spring Harbor Laboratory Press; all rights reserved; doi: 10.1101/cshperspect.a038653

Cite this article as Cold Spring Harb Perspect Med 2021;11:a038653 
K. Subbarao

the vaccine donor strain that confers ts, ca, and attenuation phenotypes on the reassortant viruses. Thus, the live vaccine viruses replicate locally in the upper respiratory tract without causing clinical illness and induce protective immunity against the circulating influenza virus.

\section{HISTORY}

This review focuses primarily on the U.S.-based ca live attenuated influenza vaccine (LAIV) with comments on the Russian ca LAIV in specific areas. The key principles underlying the development of the licensed ca LAIVs are the following.

1. A vaccine backbone strain, now referred to as a master donor virus (MDV), bears one or more attenuating mutations in one or more of the internal protein gene segments to enhance the genetic stability of the MDV.

2. The " $6: 2$ " reassortant vaccine viruses are generated by co-infection or plasmid-based reverse genetics.

3. The reassortant seasonal influenza viruses are reproducibly and reliably attenuated by transfer of the internal protein gene segments of the MDV.

4. There are separate MDVs for influenza A and $\mathrm{B}$ viruses.

The history of the U.S. ca LAIV has been reviewed previously (Murphy 1993; Maassab and Bryant 1999; Murphy and Coelingh 2002; Jin and Subbarao 2015). An important early step in the development of LAIVs was the demonstration of three independent phenotypes of the LAIV (ts, ca, and attenuation) that were reproducibly transferred to 6:2 reassortant viruses. Preclinical studies in vitro and in animal models demonstrated the independent contribution of different gene segments to these phenotypes (Snyder et al. 1988; Subbarao et al. 1992). Much later, with reliable sequence data and the availability of reverse genetics techniques, the five critical mutations in three gene segments of the MDV-A strain (Jin et al. 2003) and the five critical mutations in three gene seg- ments of the MDV-B strain (Hoffmann et al. 2005) were conclusively identified.

Preclinical studies, mainly in Golden Syrian hamsters or mice, focused on attenuation, genetic stability, immunogenicity, and efficacy of the LAIV. Hamsters were the preferred model because their body temperature was $38^{\circ} \mathrm{C}-39^{\circ} \mathrm{C}$, which was more similar to that of the lower respiratory tract of humans than that of mice, which at $37^{\circ} \mathrm{C}$ was permissive for replication of the ca LAIV in the lower respiratory tract (Mills et al. 1971; Spring et al. 1977).

In the initial steps of clinical development, monovalent $\mathrm{A} / \mathrm{H} 1 \mathrm{~N} 1$ and $\mathrm{A} / \mathrm{H} 3 \mathrm{~N} 2$ LAIV were evaluated in studies that focused on safety, infectivity, assessing the 50\% human infectious dose $\left(\mathrm{HID}_{50}\right)$ through dose escalation (or deescalation), and immunogenicity starting in healthy adults and proceeding to successively younger subjects (Murphy 1993; Maassab and Bryant 1999; Murphy and Coelingh 2002). Subsequent studies were conducted with bivalent $(\mathrm{A} / \mathrm{H} 1 \mathrm{~N} 1+\mathrm{A} / \mathrm{H} 3 \mathrm{~N} 2)$ and later trivalent (inclusion of one influenza $\mathrm{B}$ vaccine virus) formulations that assessed safety, immunogenicity, interference between strains, genetic stability, and transmissibility of the vaccine virus following close contact between vaccinees and placebo recipients in childcare centers (Murphy 1993; Murphy and Coelingh 2002). The National Institutes of Health (NIH) supported the clinical evaluation of the LAIVs in a series of studies using different strains, tested in different age groups with an exploration of virus shedding and of mucosal and systemic immune responses (Murphy 1993; Murphy and Coelingh 2002).

Commercial development of the vaccine was undertaken by Wyeth and Aviron, the latter was acquired by MedImmune and subsequently by AstraZeneca. The pivotal trial that established the efficacy of the trivalent ca LAIV was a large, randomized, placebo-controlled trial in healthy, 15- to 71-mo-old children (Belshe et al. 1998, 2000a). In the first year of the study, the vaccine was well-tolerated and efficacy was 93\% (95\% CI 88-96) against culture-confirmed influenza. There was a $29 \%$ reduction in the incidence of febrile illness and $35 \%$ reduction in febrile otitis media with concomitant antibiotic use (Belshe 
et al. 1998). In year 2 of the study, although the circulating epidemic strain influenza A/Sydney/ 97 (H3N2) was not well matched to the vaccine, the vaccine was $86 \%$ efficacious in preventing infection (Belshe et al. 2000a).

The key findings from this period of evaluation of LAIV were establishment of the efficacy of the vaccine in protection against influenza infection, including against a mismatched strain not contained in the vaccine (Belshe et al. 2000a; Mendelman et al. 2004), and vaccine effectiveness in practice, in children and adults (Nichol et al. 1999; Belshe et al. 2004; King et al. 2006; Vesikari et al. 2006; Piedra et al. 2007).

A trivalent LAIV was licensed by the U.S. Food and Drug Administration in 2003 for use in healthy individuals 5-49 yr of age. Licensure was subsequently revised to healthy individuals 2-49 yr of age, and LAIV was recommended as one of the vaccine options for healthy people in the appropriate age group by the Advisory Committee on Immunization Practices (ACIP) that advises the Centers for Disease Control and Prevention (Table 1). In 2013-2014, the U.K. Joint Committee of Vaccination and Immunisation (JCVI) recommended a single dose of LAIV to all children aged $2-16 \mathrm{yr}$, to directly protect the children themselves but also to protect other vulnerable members of the population by reducing their ability to spread influenza (Pebody et al. 2017a). The program was introduced in a phased approach and has demonstrated that vaccinating children of primary-school age is associated with reductions in incidence for a range of surveillance indicators in England (Pebody et al. 2018b). In 2007, Norway offered influenza vaccination of 6- to 35-mo-old children following a formal cost-effectiveness analysis and introduced LAIV for 2-yr-olds in 2015/16 (Nohynek et al. 2016).

During the early studies, LAIV was not compared head-to-head with the licensed inactivated influenza vaccine (IIV), but in a postmarketing study, the two products were compared in nearly 8500 children aged 6-59 mo. There were $54.9 \%$ fewer cases of influenza in the LAIV group than in the IIV group; the relative efficacy of LAIV was 79\% for influenza $\mathrm{A} / \mathrm{H} 3 \mathrm{~N} 2$ and $89 \%$ for $\mathrm{A} / \mathrm{H} 1 \mathrm{~N} 1$ infections (Belshe et al. 2007). Clinical data comparing LAIV and IIV in adults were reported in the U.S. military (Eick et al. 2009; Wang et al. 2009) and civilians (Ohmit et al. 2006, 2008; Monto et al. 2009). Unlike what was observed in children, IIV was more efficacious than LAIV in adults, although, notably, in the military, the efficacy of LAIV was more robust in vaccinenaive service members (new recruits) than in annually revaccinated personnel (Wang et al. 2009). Potential explanations for age-specific differences in efficacy included reduced ability of LAIV to infect some adults because of their prior exposure to similar strains of influenza (Eick et al. 2009; Monto et al. 2009).

Several technical improvements in the vaccine occurred over the course of time, including

Table 1. A summary of ACIP recommendations regarding the use of LAIV

\begin{tabular}{|c|c|c|}
\hline Year & Recommendation & Reference \\
\hline 2003 & $\begin{array}{l}\text { Recommended as an option for vaccination of healthy persons aged 5-49 } \mathrm{yr} \\
\text { of age. }\end{array}$ & Harper et al. 2003 \\
\hline 2014 & $\begin{array}{l}\text { When immediately available, LAIV should be used for healthy children aged } \\
2-8 \mathrm{yr} \text { who have no contraindications or precautions. }\end{array}$ & Grohskopf et al. 2014 \\
\hline 2015 & Preference of LAIV4 over IIV withdrawn. & Grohskopf et al. 2015 \\
\hline 2016 & LAIV4 should not be used for the 2016-2017 season. & Grohskopf et al. 2016 \\
\hline 2017 & LAIV4 should not be used for the 2017-2018 season. & Grohskopf et al. 2017 \\
\hline 2018 & $\begin{array}{l}\text { LAIV4 is an acceptable option for vaccination of persons for whom it is } \\
\text { appropriate. }\end{array}$ & Grohskopf et al. 2018a \\
\hline 2019 & $\begin{array}{l}\text { LAIV4 is an acceptable option for vaccination of persons for whom it is } \\
\text { appropriate. }\end{array}$ & Grohskopf et al. 2019 \\
\hline
\end{tabular}

(ACIP) Advisory Committee on Immunization Practices, (LAIV) live attenuated influenza vaccine. 
K. Subbarao

the generation of the reassortant vaccine viruses by reverse genetics instead of traditional coinfection, a transition from a trivalent to a quadrivalent vaccine (LAIV4) containing two influenza $A$ and two influenza B strains in 2013-2014 in the United States, a reduction in the volume of the vaccine to $0.2 \mathrm{~mL}$, with $0.1 \mathrm{~mL}$ administered in each nostril, and the development of a refrigerator-stable formulation in place of a product that required a freezer.

\section{EXPERIENCE WITH THE ca LAIV DURING THE 2009 PANDEMIC}

Following the public health decision that a vaccine should be produced against the 2009 $\mathrm{H} 1 \mathrm{~N} 1$ pandemic influenza virus, MedImmune Inc. rapidly developed a monovalent $\mathrm{A} /$ $\mathrm{H} 1 \mathrm{~N} 1 \mathrm{pdm} 09$ vaccine virus based on the A/California/7/2009 (CA/09) virus (Chen et al. 2010) for use in the United States. Preclinical studies in mice and ferrets revealed that the CA/09 LAIV conferred complete protection from challenge with the wild-type virus (Chen et al. 2011). The safety of the vaccine was demonstrated in children and adults (Mallory et al. 2010), and a single dose of the vaccine was demonstrated to be $69 \%$ effective in preventing H1N1pdm09 infections in school-aged children (Uzicanin et al. 2012) and $82 \%$ effective in preventing H1N1pdm09-associated hospitalization in children aged 3-9 yr (Hadler et al. 2012).

\section{CLINICAL EXPERIENCE POST-2009}

\section{CDC U.S. Influenza VE Network}

For the last decade, the Centers for Disease Control and Prevention (CDC) have implemented a systematic assessment of vaccine effectiveness (VE) through a network of five clinical sites (U.S. Influenza VE network), using observational test-negative case-control (TNCC) (also called test-negative design or TND) studies that generate estimates of VE against medically attended acute respiratory illness while reducing bias associated with health-care-seeking behavior and misclassification of cases (Sullivan et al. 2016). Patients with influenza-like illness who present to participating practices are tested for influenza; those testing positive for influenza virus are defined as cases, and those testing negative form the comparison group. VE is estimated by comparing the odds of testing positive for influenza among vaccinated and unvaccinated patients, adjusting for confounders.

VE data from three observational studies in the 2013-2014 season (the first season in which LAIV4 was available) revealed low effectiveness of LAIV against H1N1pdm09 in 2- to 17-yr-old children. Analysis of VE data from the U.S. Influenza VE network for 2010-2011 through 2013-2014 seasons revealed that children aged 2-17 yr had similar odds of influenza regardless of receipt of LAIV3 or IIV3 during 2010-2011 through 2012-2013. However, in 2013-2014, the first season of $\mathrm{H} 1 \mathrm{~N} 1 \mathrm{pdm} 09$ predominance since the 2009 pandemic, the odds of influenza were significantly higher for 2- to 17-yr-old LAIV4 recipients (OR 2.88; 95\% CI 1.62-5.12). The observation that VE of the LAIV against influenza A/H1N1pdm09 was consistently lower than that for IIV prompted the ACIP to change their recommendation for the preferential use of LAIV in children (Table 1; Campbell and Grohskopf 2018). Additionally, in 2014-2015, when an $\mathrm{A} / \mathrm{H} 3 \mathrm{~N} 2$ drift variant circulated, the U.S. Influenza VE network found that neither LAIV4 nor IIV provided significant protection in 2- to 17-yr-old children and LAIV did not offer greater protection than IIV. A systematic review and meta-analysis of the VE against influenza $\mathrm{A} / \mathrm{H} 3 \mathrm{~N} 2$ viruses, the dominant circulating strain during the 2016-2017 season, revealed comparable effectiveness of $51 \%$ and $46 \%$, respectively, for LAIV4 and IIV (Mallory et al. 2020a).

In 2015-2016, the manufacturer (MedImmune/AstraZeneca) replaced CA/09 (H1N1 pdm09) with A/Bolivia/559/2013 (H1N1pdm 09), but in the subsequent season the U.S. Influenza VE network found no significant VE (3\%; 95\% CI -49-37) for LAIV4 against all influenza $A$ and $B$ viruses combined in 2- to 17-yr-olds or for influenza A/H1N1pdm09 (-21\%; CI -10830) (Grohskopf et al. 2016). A U.S. Department of Defense analysis similarly noted no VE in this age group for the 2015-2016 season. An obser- 
vational study funded by the manufacturer reported a higher point estimate of VE, but it was not statistically significant (Poehling et al. 2018). In contrast, IIV was effective in all three studies (Table 2). The ACIP recommended that LAIV4 should not be used for the 2016-2017 and 20172018 seasons (Table 1 ).

\section{Clinical Experience beyond the U.S. VE Network}

Notably, VE estimates were not consistent among all studies in the United States (Poehling et al. 2018) and in countries outside the United States (Canada, United Kingdom, Norway, and Germany) that used LAIV (Table 2); VE estimates in the United Kingdom, Norway, and Canada were comparable to previous seasons and were markedly higher than those observed in the U.S. Influenza VE network (Pebody et al. 2016b, 2017a,b, 2018a, 2019; Buchan et al. 2018). These findings were summarized in a metaanalysis (Fig. 1; Caspard et al. 2017); although the point estimates varied, many were not statistically significant (https://www.cdc.gov/flu/ professionals/acip/immunogenicity.htm). Although a satisfactory explanation has not yet been found for the inconsistent point estimates, the effectiveness of LAIV against H1N1pdm09 was lower than that of IIV (Caspard et al. 2017).

In addition to the observational studies, three randomized studies were conducted since 2009 and are summarized in Caspard et al. (2017).

1. A cluster-randomized, IIV-controlled study in school-aged children in Ontario, Canada, an open label study in 10 elementary schools conducted in 2013-2014 that demonstrated greater protection with LAIV3 than TIV for children and their household contacts in a season dominated by H1N1pdm09 (Kwong et al. 2015).

2. A community-randomized IIV-controlled study in Hutterite communities in Canada, conducted October 2012-May 2015, in which the incidence rate of influenza among vaccine recipients did not differ by vaccine type (Loeb et al. 2016).
3. A placebo-controlled study in more than 1200 Japanese children aged 7-18 yr who were randomized to receive LAIV4 or placebo in 2014-2015, a season dominated by A/H3N2. LAIV4 efficacy against circulating $\mathrm{A} / \mathrm{H} 3 \mathrm{~N} 2$ strains, all of which were mismatched to the vaccine, was $25.4 \%$ (95\% CI 4.3-41.7) (Mallory et al. 2018).

The data from the randomized controlled trials were generally consistent with the observational studies: Efficacy against H1N1pdm09 was not consistently demonstrated, and although efficacy against mismatched $\mathrm{H} 3 \mathrm{~N} 2$ strains was significant, the point estimate was low.

\section{POTENTIAL EXPLANATIONS FOR POOR VE AGAINST H1N1pdm09 VIRUSES AND SUBSEQUENT ACTION}

Several potential explanations have been proposed for the observed lack of effectiveness of LAIV against H1N1pdm09 viruses (Ambrose et al. 2016; Penttinen and Friede 2016; Singanayagam et al. 2018; Belshe 2019). These include reduced stability and infectivity of the CA/09 (H1N1pdm09) vaccine virus, conferred by a single amino acid substitution in the HA stalk (Cotter et al. 2014), exposure of some vaccine lots to temperatures above those recommended for storage (Caspard et al. 2016), vaccine virus interference associated with the introduction of the fourth virus in LAIV4 (although the fact that low VE was seen with LAIV3 makes this unlikely), and differences in prior vaccine coverage among children contributing to differences in replicative fitness in different populations, leading to differences in VE, although the U.S. Influenza VE network found no significant effect of prior vaccination (Caspard et al. 2017; McLean et al. 2018).

A detailed analysis by the manufacturer concluded that reduced replicative fitness of both CA/09 and A/Bolivia/559/2013 (H1N1pdm09) strains was the primary root cause of poor VE against circulating H1N1pdm09 viruses. New assays using human nasal epithelial cells and tissue culture infectious dose 50 assays that require multiple rounds of virus replication were 

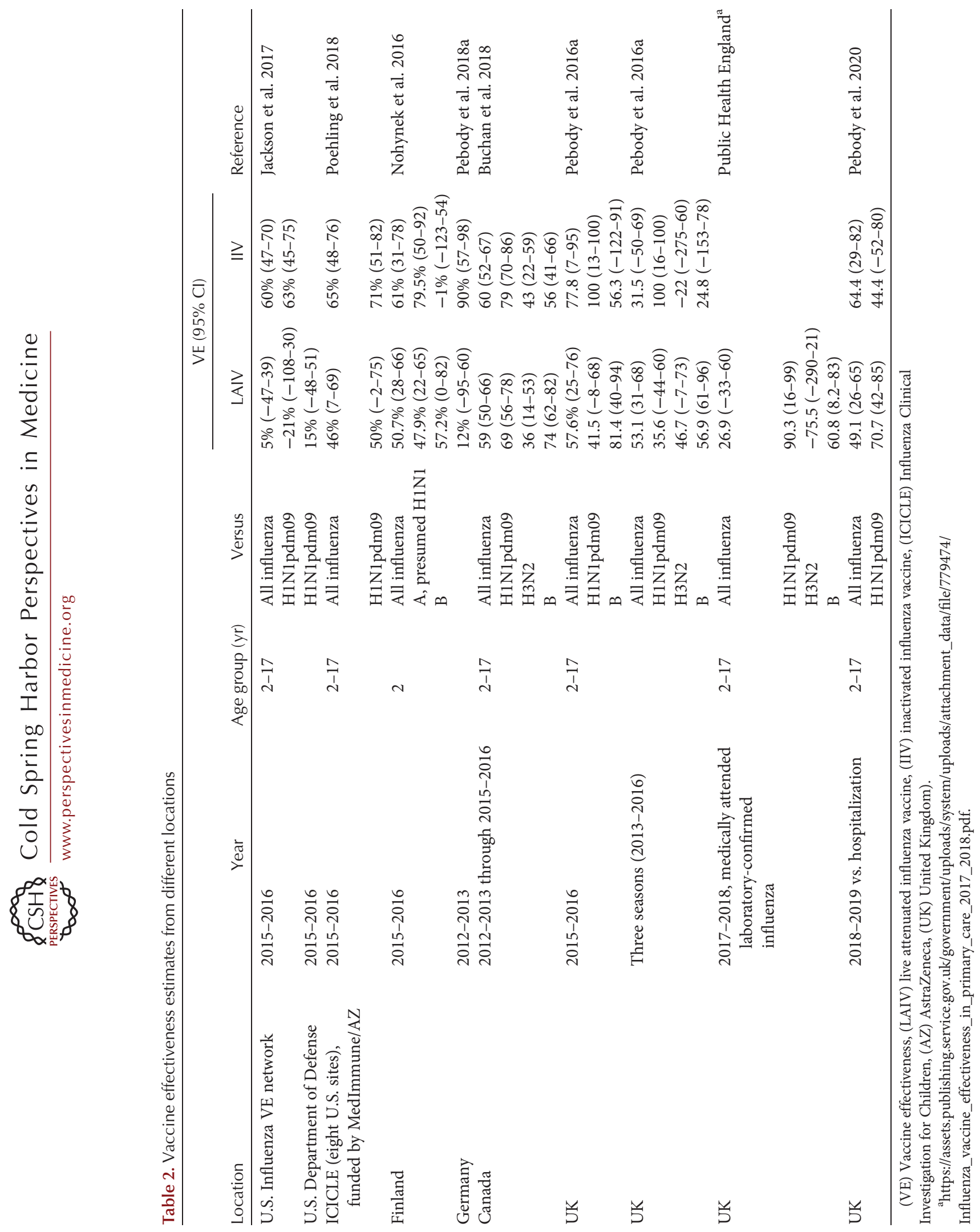
Live Attenuated Cold-Adapted Influenza Vaccines
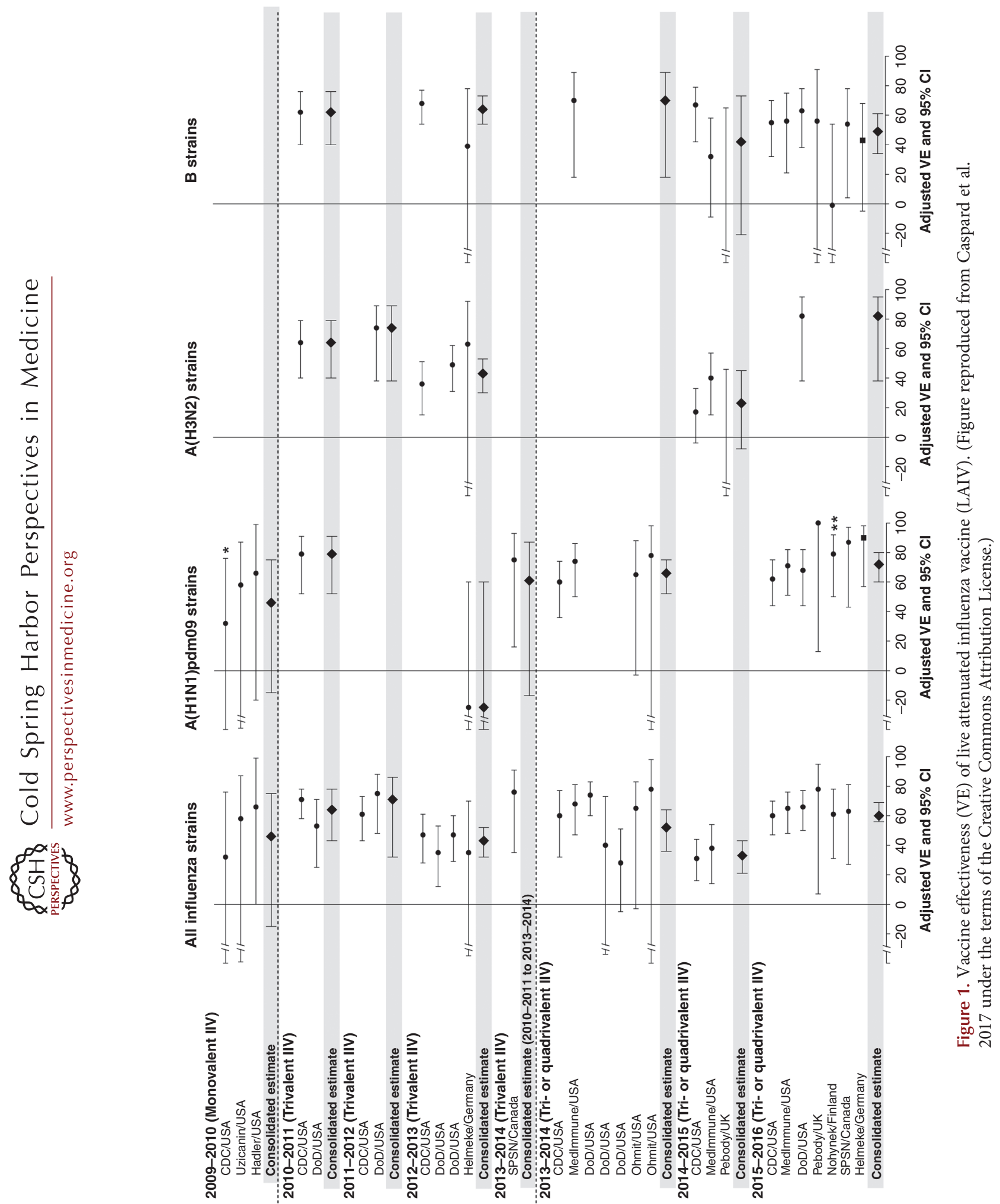
introduced for assessment of potency, and A/Slovenia/293/2015 (H1N1pdm09) was selected for inclusion in the vaccine. The infectivity of the vaccine virus measured by shedding of the vaccine virus was assessed in 200 children aged 2-4 yr who received LAIV3 containing A/Bolivia/559/2013, LAIV4 containing A/Bolivia/559/ 2013, or LAIV4 containing A/Slovenia/293/ 2015. A/Slovenia/293/2015 was shed by a higher proportion of children than the comparators, and seroconversion rates were similar to prepandemic H1N1s when LAIV was effective (Mallory et al. 2020b).

The ACIP reviewed these data and also discussed combined individual patient level data of VE of LAIV4 and IIV during the 2013-2014 through 2015-2016 seasons, data pooled from five U.S. observational studies (Chung et al. 2019), a systematic review and meta-analysis of LAIV effectiveness for the 2010-2011 through 2016-2017 seasons from the United States and elsewhere (Grohskopf et al. 2018b). These analyses revealed that although LAIV4 was poorly effective or ineffective against H1N1pdm09 viruses in most studies, it was generally effective against influenza $B$ viruses and generally no less effective than IIV against $\mathrm{H} 3 \mathrm{~N} 2$ viruses. For the 2018-2019 and 2019-2020 seasons, the ACIP recommended that LAIV4 was an acceptable option for vaccination of persons for whom it was appropriate (Table 1).

\section{EXPERIENCE WITH RUSSIAN-BACKBONE LAIV}

The effectiveness of the Russian LAIV was compared with IIV and placebo in school children in Novgorod, Russia, over a 2-yr period (Rudenko et al. 1993). In individuals and school-based comparisons, LAIV given in two doses was more protective than one dose of IIV. An indirect effect of vaccination on unvaccinated students and staff was found in schools in which students received LAIV (Rudenko et al. 1993). LAIV has since been widely used in Russia. Russian-backbone LAIV seed strains were provided to developing country manufacturers for pandemic preparedness, through an intellectual property program initiated by the World Health
Organization (WHO) (Rudenko et al. 2011). A monovalent H1N1pdm09 LAIV was manufactured by Serum Institute of India, Ltd (SIIL) and demonstrated VE of 76\% (95\% CI 42-90) in a case control study in 2010 (Kulkarni et al. 2014).

A seasonal trivalent LAIV manufactured by SIIL was tested in a randomized, placebo-controlled phase 2 study in 300 24- to 59-mo-old children in urban Bangladesh (Ortiz et al. 2015), in which the vaccine was well-tolerated and safe (Ortiz et al. 2015). No child shed the A/H1N1 vaccine strain, but $45 \%$ and $67 \%$ shed the A/H3N2 or influenza B vaccine viruses, respectively (Lewis et al. 2019). Serum and mucosal antibody responses to influenza $\mathrm{A} / \mathrm{H} 3 \mathrm{~N} 2$ and $B$ were observed, but only a mucosal IgA response to A/H1N1 was seen. Thus, the infectivity and immunogenicity of the H1N1pdm09 component of the vaccine were very low.

This was followed by a two-site randomized double-blind, placebo-controlled, parallel-group trial in which 1174 children aged 2-4 yr received a single dose of Russian-backbone LAIV and 587 received placebo. The vaccine had a good safety profile, and laboratory-confirmed influenza illness due to vaccine-matched strains was seen in 93 (15.8\%) of children in the placebo group and $79(6.7 \%)$ in the LAIV group, resulting in VE of 57.7 (95\% CI 44-68). There was no efficacy against the mismatched influenza B strain (Brooks et al. 2016).

In striking contrast to the results from Bangladesh, a randomized double-blind, placebocontrolled, parallel-group, single-center trial conducted in Senegal in which 1174 children aged 2-5 yr received a single dose of Russianbackbone LAIV and 587 received placebo revealed no protection against symptomatic laboratory-confirmed influenza. Influenza incidence was high ( 20\% attack rate), with 210 (18\%) endpoints of infection in the LAIV group and 105 (18\%) among placebo recipients, resulting in VE of $0.0 \%$ (95\% CI -26-21). Vaccine-mismatched influenza B was the dominant circulating strain; influenza A/H1N1pdm09 appeared midway through the trial and circulated extensively till the end of the study period. Analysis of secondary endpoints caused by vaccinematched strains and by type and subtype or lin- 
Live Attenuated Cold-Adapted Influenza Vaccines

eage also revealed no statistical evidence for vaccine efficacy (Victor et al. 2016). Shedding of at least one vaccine virus was reported in $55(83 \%)$ of 66 LAIV recipients but immunogenicity was not assessed. Although nearly one-half of the participants in the Senegal study had been previously vaccinated with IIV, randomization ensured equal distribution in the LAIV and placebo groups. Potential explanations for the differences in the results of the studies in Bangladesh and Senegal that have been considered and largely discounted include differences in potency of the vaccine, previous history of influenza exposure, ecology of the nasopharynx, nutritional deficiencies that might differentially affect replication of the vaccine virus, or a history of recent receipt of oral polio vaccine (Isakova-Sivak et al. 2020).

The poor VE in the Senegal study was more consistent with that reported by the U.S. VE network with the U.S.-backbone LAIV than with that reported with the Russian-backbone LAIV in Bangladesh (Victor et al. 2016). The replicative fitness of the H1N1pdm09 vaccine strain (CA/09) in the LAIV was an ongoing concern. The vaccine strain was updated to an A/Michigan/45/2015-like strain (New York/15/ 5364; NY15), and in 2017, a prospective, open-label observational phase 4 study of the Russian-backbone trivalent LAIV with the updated H1N1pdm09 strain was undertaken in influenza vaccine-naive children aged 24-59 mo in a peri-urban area of The Gambia (Lindsey et al. 2019). Vaccine virus shedding and immunogenicity were compared among children who received one dose of LAIV containing CA/09 or NY15 H1N1pdm09 strains. Only 16 (14\%) of 118 who received the CA/09 LAIV shed the $\mathrm{H} 1 \mathrm{~N} 1$ vaccine virus and $6(5 \%)$ seroconverted, whereas 80 (63\%) of 126 who received the NY15 LAIV shed vaccine virus and 24 (19\%) seroconverted. The NY15 strain also induced more robust $\mathrm{T}$-cell immunity than CA/09 (Lindsey et al. 2019). These data are consistent with the improved shedding indicative of replicative fitness with the U.S.-backbone LAIV containing A/Slovenia/2015 in place of CA/09 and suggest that the poor VE with the Russian-backbone LAIV observed in
Senegal may be overcome with a different vaccine strain.

\section{CORRELATES OF PROTECTION}

Immune markers that predict protection from infection or disease are referred to as correlates of protection. The definition is not always clearly stated, resulting in calls to clarify the terminology and build statistical or epidemiological frameworks for assessing correlates of protection (Qin et al. 2007; Plotkin 2008; Gilbert et al. 2019; Lim et al. 2019).

Neutralizing antibodies in the serum and at the mucosal surface are sufficient to prevent influenza infection; $\mathrm{CD}^{+} \mathrm{T}$ cells provide necessary help in B-cell development and $\mathrm{CD}^{+}$ T cells mediate viral clearance. An experimental challenge study with influenza virus established that a serum hemagglutination inhibition (HAI) antibody titer of 1:32 (or 1:40, depending on the dilution series) was associated with a 50\% reduction in risk of contracting influenza in a susceptible population and is referred to as the $50 \%$ protective titer (Hobson et al. 1972). Conventionally, an HAI titer of 1:40 is often referred to as "seroprotective" and is widely regarded as the correlate of protection for IIV. However, a model based on a meta-analysis of published studies demonstrated that the relationship between HAI antibody titer and protection is better described by a curve, rather than a simple threshold value (Plotkin 2008; Coudeville et al. 2010). A progressive increase in protection was noted with increasing HAI titer, particularly at titers of up to 1:100, irrespective of vaccination status or viral strain (Coudeville et al. 2010).

In contrast to IIV, it has been very difficult to identify a single correlate of protection for LAIV. In adults, resistance to wild-type virus infection following LAIV correlated with nasal wash IgA antibody and serum antibodies to NA (Clements et al. 1986), whereas in children the presence of any serum HAI antibody or nasal wash IgA antibody provided significant protection from virus shedding (Belshe et al. 2000b). Data from three prospective randomized studies comparing LAIV with placebo in children 6-36 mo of age revealed that nasal IgA contrib- 
utes to the efficacy of LAIV, although the inherent heterogeneity in nasal antibody and variability in nasal specimen collection hinders the precise evaluation of mucosal antibody responses (Ambrose et al. 2012).

Notably, however, even in the absence of detectable serum or nasal antibodies, LAIV-vaccinated children have fewer challenge infections than placebo recipients ( 4 of 16 vs. 16 of 35 in one study), indicating that they were protected by some other, unmeasured factor (Belshe et al. 2000b). In fact, in the 16 LAIV and 35 placebo recipients who lacked both serum HAI and nasal wash IgA antibodies, neutralizing antibodies were detected by microneutralization assay in the sera of 12 LAIV recipients but only one placebo recipient (Belshe et al. 2000b).

A detailed analysis that included 39 strainspecific assays of serum and mucosal immune responses to LAIV in children failed to identify a single measure that was predictive of protection (Wright et al. 2016). Data from a study comparing VE of IIV and LAIV in healthy adults were analyzed using a principal stratification/VE moderation framework, a statistical method for assessing how VE varies over subgroups defined by biomarkers measuring immune responses in vaccinees. The authors found no evidence that LAIV efficacy depended on previous vaccination, baseline HAI or NAI titer, or any postvaccination titer markers, although there was limited precision in the study to learn about modifiers of LAIV VE (Gilbert et al. 2019).

A similar issue has been noted with the Russian-backbone LAIV (Brooks et al. 2016; Lewis et al. 2019). Vaccinees with lower baseline immunity to influenza had significantly higher odds of shedding a vaccine virus in the week following administration of the vaccine, and the magnitude of immune responses was most pronounced in children with detectable virus shedding (Brickley et al. 2019), but neither vaccine virus recovery nor immunologic response was fully predictive of a protective response to the Russian-backbone LAIVs (Brickley et al. 2019).

In summary, serum and mucosal antibodies are "co-correlates" of protection, defined as one of two or more correlates of protection, that may be synergistic with other correlates (Plotkin 2008). Although high rates of seroconversion are associated with high efficacy, efficacy of LAIV is also observed with low rates of seroconversion (Bandell et al. 2011). No single assay predicts protection, but the range of available assays and sophisticated technical advances may lead to the identification of one, or an algorithm that incorporates different immunologic responses, that will predict LAIV-mediated protection.

\section{PANDEMIC LAIV}

Following the identification of avian $\mathrm{H} 5 \mathrm{~N} 1$ and H9N2 virus infections in humans, the $\mathrm{NIH}$ undertook a pandemic influenza vaccine development program in 2003 under a collaborative research and development agreement with MedImmune, using the U.S. LAIV platform. This approach was selected because the technology was licensed; seasonal LAIV was optimally balanced in attenuation and efficacy, LAIV-induced serum and mucosal antibody responses, $\mathrm{T}$-cell responses, and broader cross-protection against antigenic drift variants, and seasonal LAIV had greater yield per egg than IIV (Rudraraju et al. 2019) The HA and NA gene segments of the pandemic LAIVs (pLAIVs) were derived from avian influenza viruses of different subtypes, including $\mathrm{H} 2, \mathrm{H} 5, \mathrm{H} 6, \mathrm{H} 7$, and $\mathrm{H} 9$, on a backbone of six internal protein genes of the influenza A MDV, that conferred ts and attenuation phenotypes. Known virulence motifs in the HA such as the multibasic amino acid cleavage site in $\mathrm{H} 5$ and some $\mathrm{H} 7$ viruses were removed by genetic engineering ( $\mathrm{Li}$ et al. 1999; Min et al. 2010). The candidate pLAIVs were evaluated extensively in preclinical studies in mice and/or ferrets and, based on promising results, were advanced to phase I clinical trials for assessment of their safety in healthy adults. Eight pLAIVs representing five avian influenza subtypes were well-tolerated on clinical evaluation (Karron et al. 2009a,b; Talaat et al. 2009, 2011, 2013; Babu et al. 2014; Sobhanie et al. 2016). However, the vaccines were highly restricted in replication and were poorly immunogenic (Karron et al. 2009a,b; Talaat et al. 2009, 
2011, 2013; Babu et al. 2014; Sobhanie et al. 2016). This was surprising for two reasons: first, because pLAIVs had replicated well and were immunogenic in mice and ferrets, and, second, because the healthy adults who received the pLAIV had no prior exposure to avian influenza viruses. Several potential explanations were investigated including the sialic acid receptor preference of the pLAIVs and inhibition of vaccine virus replication by anti-NA antibodies induced against human NAs cross-reacting with avian NAs or by cross-reactive T-cell responses (Peng et al. 2015), but none provided a satisfactory explanation for the restricted replication and immunogenicity in humans.

Russian-backbone pandemic LAIVs were also developed and evaluated in preclinical and clinical trials; some were 7:1 reassortant viruses bearing only the HA gene segment from a virus with pandemic potential (Rudenko and Isakova-Sivak 2015). Although they were not directly compared in a clinical trial, vaccine virus shedding and immunogenicity of the Russianbased pandemic LAIVs appeared to be greater than the U.S.-based pandemic LAIVs, a difference that was speculated to be due to differences in infectivity of the vaccine viruses. A direct comparison of $\mathrm{H} 5 \mathrm{~N} 2$ vaccines on the Russian and U.S.-based LAIV backbones in the ferret model showed no differences in infectivity, immunogenicity, and protective efficacy, suggesting that the differences in the clinical performance of the vaccines were due to factors other than the inherent biological properties of the two MDVs (Czakó et al. 2018).

In the meantime, several studies were published reporting that administration of a booster dose of subunit H5N1 pIIV to subjects previously primed with a variety of $\mathrm{H} 5$ vaccines (recombinant expressed $\mathrm{H} 5 \mathrm{HA}$, DNA encoding H5 HA, or an $\mathrm{H} 5 \mathrm{~N} 1 \mathrm{pIIV}$ ) resulted in a robust $\mathrm{HAI}$ and neutralizing antibody responses, even in individuals who had no detectable antibody response following initial vaccination (Rudraraju et al. 2019). A series of clinical trials was undertaken in which recipients of $\mathrm{H} 5$ or $\mathrm{H} 7$ pLAIVs were recalled or prospectively enrolled to receive sequential doses of matched pLAIV and pIIV (Babu et al. 2014; Talaat et al. 2014; Sobhanie et al. 2016). A great majority (64\%-79\%) of the pLAIV-primed individuals had a robust and rapid antibody response (geometric mean HAI titer 119 to 175 ) to a booster dose of the corresponding pIIV administered 3 mo to nearly 5 yr later. The antibody was highly cross-reactive with other strains within the same subtype. These data proved that pLAIVs establish long-lasting immune memory that could be recalled with a single dose of pIIV (Rudraraju et al. 2019). These findings with pLAIV were consistent with reports of robust antibody responses in subjects boosted with pIIV following priming with DNA or adenovirus expressing the H5 HA (Ledgerwood et al. 2011; Gurwith et al. 2013; Khurana et al. 2013). Notably, similar observations have been reported with an H5 Russian-backbone pLAIV (Pitisuttithum et al. 2017).

The immunologic basis for the pLAIV/pIIV prime-boost phenomenon was investigated in an African green monkey model (Matsuoka et al. 2014; Jegaskanda et al. 2018), which revealed that intranasally administered pLAIV elicited a highly localized and somatically hypermutated germinal center B-cell response in the mediastinal lymph nodes, which was rapidly recalled following pIIV boost to germinal center reactions at distant immune sites, most notably the local draining axillary lymph node (Jegaskanda et al. 2018). It is plausible that the primary immune response to LAIV in humans is similarly restricted to a draining lymph node; this may explain why serum antibody is not a reliable correlate of immunity for seasonal and pandemic LAIVs (Jegaskanda et al. 2018).

The magnitude and quality of the antibody response following sequential administration of pLAIV and pIIV are superior to unadjuvanted pIIV (Babu et al. 2014; Talaat et al. 2014), and this approach merits further consideration and development for pandemic preparedness efforts because it can generate broad immunity within a novel avian influenza subtype.

\section{CONCLUDING REMARKS}

The attractive features of LAIV include ease of administration, stimulation of systemic and mucosal antibodies, a T-cell response that can con- 
K. Subbarao

fer greater breadth of protection than IIV, reduction in the spread of influenza conferring indirect protection to unvaccinated contacts, and cost-effectiveness. The WHO has recognized that LAIVs have the potential to address the unmet need for an influenza vaccine for young children that is programmatically suitable for low- and middle-income countries (Penttinen and Friede 2016). In the area of pandemic preparedness, LAIVs have additional advantages over IIVs, including the establishment of longlasting B-cell memory that can be recalled rapidly, resulting in high-titer, high-quality, and cross-reactive antibodies; also, the yield of LAIV in embryonated eggs is greater than that of IIV, and this may be an important consideration in the event of a pandemic. However, despite the very impressive performance of LAIV in early clinical trials, some troubling observations have been made in the last decade with both the U.S. and Russian-backbone LAIVs that include the inconsistent VE of LAIV4 containing H1N1pdm09 viruses, inconsistent findings with the Russian-backbone LAIV in Bangladesh and Senegal, and the lack of reliable correlates of protection. It will be important to understand the biological basis for these findings and develop practical strategies to identify and avoid selecting LAIV strains that are overattenuated (Belshe 2019) in order to take full advantage of these valuable vaccines and implement them in our public health systems.

\section{ACKNOWLEDGMENTS}

The Melbourne WHO Collaborating Centre for Reference and Research on Influenza is supported by the Australian Government Department of Health.

This article has been made freely available online courtesy of TAUNS Laboratories.

\section{REFERENCES}

Ambrose CS, Wu X, Jones T, Mallory RM. 2012. The role of nasal $\operatorname{IgA}$ in children vaccinated with live attenuated influenza vaccine. Vaccine 30: 6794-6801. doi:10.1016/j .vaccine.2012.09.018
Ambrose CS, Bright H, Mallory R. 2016. Letter to the editor: potential causes of the decreased effectiveness of the influenza A(H1N1)pdm09 strain in live attenuated influenza vaccines. Euro Surveill 21: 30394. doi:10.2807/15607917.ES.2016.21.45.30394

Babu TM, Levine M, Fitzgerald T, Luke C, Sangster MY, Jin H, Topham D, Katz J, Treanor J, Subbarao K. 2014. Live attenuated H7N7 influenza vaccine primes for a vigorous antibody response to inactivated H7N7 influenza vaccine. Vaccine 32: 6798-6804. doi:10.1016/j.vaccine.2014.09 .070

Bandell A, Woo J, Coelingh K. 2011. Protective efficacy of live-attenuated influenza vaccine (multivalent, Ann Arbor strain): a literature review addressing interference. Expert Rev Vaccines 10: 1131-1141. doi:10.1586/erv.11 .73

Belshe RB. 2019. The potential of live, attenuated influenza vaccine for the prevention of influenza in children. Clin Infect Dis 69: 795-796. doi:10.1093/cid/ciy1007

Belshe RB, Mendelman PM, Treanor J, King J, Gruber WC, Piedra P, Bernstein DI, Hayden FG, Kotloff K, Zangwill K et al. 1998. The efficacy of live attenuated, cold-adapted, trivalent, intranasal influenza virus vaccine in children. $N$ Engl J Med 338: 1405-1412. doi:10.1056/NEJM 199805143382002

Belshe RB, Gruber WC, Mendelman PM, Cho I, Reisinger K, Block SL, Wittes J, Iacuzio D, Piedra P, Treanor J, et al. 2000a. Efficacy of vaccination with live attenuated, coldadapted, trivalent, intranasal influenza virus vaccine against a variant (A/Sydney) not contained in the vaccine. J Pediatr 136: 168-175. doi:10.1016/S0022-3476(00) 70097-7

Belshe RB, Gruber WC, Mendelman PM, Mehta HB, Mahmood K, Reisinger K, Treanor J, Zangwill K, Hayden FG, Bernstein DI, et al. 2000b. Correlates of immune protection induced by live, attenuated, cold-adapted, trivalent, intranasal influenza virus vaccine. J Infect Dis 181: 11331137. doi:10.1086/315323

Belshe RB, Nichol KL, Black SB, Shinefield H, Cordova J, Walker R, Hessel C, Cho I, Mendelman PM. 2004. Safety, efficacy, and effectiveness of live, attenuated, cold-adapted influenza vaccine in an indicated population aged 5-49 years. Clin Infect Dis 39: 920-927. doi:10.1086/423001

Belshe RB, Edwards KM, Vesikari T, Black SV, Walker RE, Hultquist M, Kemble G, Connor EM, CAIV-T Comparative Efficacy Study Group. 2007. Live attenuated versus inactivated influenza vaccine in infants and young children. $N$ Engl J Med 356: 685-696. doi:10.1056/NEJ Moa065368

Brickley EB, Wright PF, Khalenkov A, Neuzil KM, Ortiz JR, Rudenko L, Levine MZ, Katz JM, Brooks WA. 2019. The Effect of preexisting immunity on virus detection and immune responses in a phase II, randomized trial of a Russian-backbone, live, attenuated influenza vaccine in Bangladeshi children. Clin Infect Dis 69: 786-794. doi:10.1093/cid/ciy1004

Brooks WA, Zaman K, Lewis KD, Ortiz JR, Goswami D Feser J, Sharmeen AT, Nahar K, Rahman M, Rahman $\mathrm{MZ}$, et al. 2016. Efficacy of a Russian-backbone live attenuated influenza vaccine among young children in Bangladesh: a randomised, double-blind, placebo-con- 
trolled trial. Lancet Glob Health 4: e946-e954. doi:10 .1016/S2214-109X(16)30200-5

Buchan SA, Booth S, Scott AN, Simmonds KA, Svenson LW, Drews SJ, Russell ML, Crowcroft NS, Loeb M, Warshawsky BF, et al. 2018. Effectiveness of live attenuated vs inactivated influenza vaccines in children during the 2012-2013 through 2015-2016 influenza seasons in Alberta, Canada: a Canadian Immunization Research Network (CIRN) Study. JAMA Pediatr 172: e181514. doi:10 .1001/jamapediatrics.2018.1514

Campbell AJP, Grohskopf LA. 2018. Updates on influenza vaccination in children. Infect Dis Clin North Am 32: 75 89. doi:10.1016/j.idc.2017.11.005

Caspard H, Coelingh KL, Mallory RM, Ambrose CS. 2016. Association of vaccine handling conditions with effectiveness of live attenuated influenza vaccine against H1N1pdm09 viruses in the United States. Vaccine 34: 5066-5072. doi:10.1016/j.vaccine.2016.08.079

Caspard H, Mallory RM, Yu J, Ambrose CS. 2017. Liveattenuated influenza vaccine effectiveness in children from 2009 to 2015-2016: a systematic review and metaanalysis. Open Forum Infect Dis 4: ofx111. doi:10.1093/ ofid/ofx111

Chen Z, Wang W, Zhou H, Suguitan AL Jr, Shambaugh C, Kim L, Zhao J, Kemble G, Jin H. 2010. Generation of live attenuated novel influenza virus A/California/7/09 $(\mathrm{H} 1 \mathrm{~N} 1)$ vaccines with high yield in embryonated chicken eggs. J Virol 84: 44-51. doi:10.1128/JVI.02106-09

Chen GL, Min JY, Lamirande EW, Santos C, Jin H, Kemble G, Subbarao K. 2011. Comparison of a live attenuated 2009 H1N1 vaccine with seasonal influenza vaccines against 2009 pandemic H1N1 virus infection in mice and ferrets. J Infect Dis 203: 930-936. doi:10.1093/in fdis/jiq144

Chung JR, Flannery B, Ambrose CS, Bégué RE, Caspard H, DeMarcus L, Fowlkes AL, Kersellius G, Steffens A, Fry AM, et al. 2019. Live attenuated and inactivated influenz vaccine effectiveness. Pediatrics 143: e20182094. doi:10 .1542/peds.2018-2094

Clements ML, Betts RF, Tierney EL, Murphy BR. 1986. Serum and nasal wash antibodies associated with resistance to experimental challenge with influenza A wild-type virus. J Clin Micro 24: 157-160. doi:10.1128/JCM.24.1.157160.1986

Cotter CR, Jin H, Chen Z. 2014. A single amino acid in the stalk region of the H1N1pdm influenza virus HA protein affects viral fusion, stability and infectivity. PLoS Pathog 10: e1003831. doi:10.1371/journal.ppat.1003831

Coudeville L, Bailleux F, Riche B, Megas F, Andre P, Ecochard R. 2010. Relationship between haemagglutinationinhibiting antibody titres and clinical protection against influenza: development and application of a bayesian random-effects model. BMC Med Res Methodol 10: 18 doi:10.1186/1471-2288-10-18

Czakó R, Vogel L, Sutton T, Matsuoka Y, Krammer F, Chen Z, Jin H, Subbarao K. 2018. H5N2 vaccine viruses on Russian and US live attenuated influenza virus backbones demonstrate similar infectivity, immunogenicity and protection in ferrets. Vaccine 36: 1871-1879. doi:10.1016/j vaccine.2018.02.061

Eick AA, Wang Z, Hughes H, Ford SM, Tobler SK. 2009. Comparison of the trivalent live attenuated vs. inactivated influenza vaccines among U.S. military service members. Vaccine 27: 3568-3575. doi:10.1016/j.vaccine.2009.03 088

Ghendon YZ, Polezhaev FI, Lisovskaya KV, Medvedeva TE, Alexandrova GI, Klimov AI. 1984. Recombinant coldadapted attenuated influenza $\mathrm{A}$ vaccines for use in children: molecular genetic analysis of the cold-adapted donor and recombinants. Infect Immun 44: 730-733. doi:10.1128/IAI.44.3.730-733.1984

Gilbert PB, Fong Y, Juraska M, Carpp LN, Monto AS, Martin ET, Petrie JG. 2019. HAI and NAI titer correlates of inactivated and live attenuated influenza vaccine efficacy. BMC Infect Dis 19: 453. doi:10.1186/s12879-019-4049-5

Grohskopf LA, Olsen SJ, Sokolow LZ, Bresee IS, Cox NJ, Broder KR, Karron RA, Walter EB, Centers for Disease Control and Prevention. 2014. Prevention and control of seasonal influenza with vaccines: recommendations of the Advisory Committee on Immunization Practices (ACIP) -United States, 2014-15 influenza season. MMWR Morb Mortal Wkly Rep 63: 691-697.

Grohskopf LA, Sokolow LZ, Olsen SJ, Bresee JS, Broder KR, Karron RA. 2015. Prevention and control of influenza with vaccines: recommendations of the Advisory Committee on Immunization Practices, United States, 201516 Influenza Season. Am J Transplant 15: 2767-2775. doi:10.1111/ajt.13505

Grohskopf LA, Sokolow LZ, Broder KR, Olsen SJ, Karron RA, Jernigan DB, Bresee JS. 2016. Prevention and control of seasonal influenza with vaccines. MMWR Recomm Rep 65: 1-54. doi:10.15585/mmwr.rr6505a1

Grohskopf LA, Sokolow LZ, Broder KR, Walter EB, Bresee JS, Fry AM, Jernigan DB. 2017. Prevention and control of seasonal influenza with vaccines: recommendations of the Advisory Committee on Immunization Practices-United States, 2017-18 Influenza Season. MMWR Recomm Rep 66: 1-20. doi:10.15585/mmwr.rr6602al

Grohskopf LA, Sokolow LZ, Broder KR, Walter EB, Fry AM, Jernigan DB. 2018a. Prevention and control of seasonal influenza with vaccines: recommendations of the Advisory Committee on Immunization Practices-United States, 2018-19 Influenza Season. MMWR Recomm Rep 67: 1-20. doi:10.15585/mmwr.rr6703a1

Grohskopf LA, Sokolow LZ, Fry AM, Walter EB, Jernigan DB. 2018b. Update: ACIP recommendations for the use of quadrivalent live attenuated influenza vaccine (LAIV4) United States, 2018-19 Influenza Season. MMWR Morb Mortal Wkly Rep 67: 643-645. doi:10.15585/mmwr .mm6722a5

Grohskopf LA, Alyanak E, Broder KR, Walter EB, Fry AM, Jernigan DB. 2019. Prevention and control of seasonal influenza with vaccines: recommendations of the Advisory Committee on Immunization Practices-United States, 2019-20 Influenza Season. MMWR Recomm Rep 68: 1-21. doi:10.15585/mmwr.rr6803a1

Gurwith M, Lock M, Taylor EM, Ishioka G, Alexander J, Mayall T, Ervin JE, Greenberg RN, Strout C, Treanor JJ, et al. 2013. Safety and immunogenicity of an oral, replicating adenovirus serotype 4 vector vaccine for H5N influenza: a randomised, double-blind, placebo-controlled, phase 1 study. Lancet Infect Dis 13: 238-250. doi:10.1016/S1473-3099(12)70345-6 
K. Subbarao

Hadler JL, Baker TN, Papadouka V, France AM, Zimmerman C, Livingston KA, Zucker JR. 2012. Effectiveness of 1 dose of 2009 influenza A (H1N1) vaccine at preventing hospitalization with pandemic H1N1 influenza in children aged 7 months-9 years. J Infect Dis 206: 49-55. doi:10.1093/infdis/jis306

Harper SA, Fukuda K, Cox NJ, Bridges CB, Advisory Committee on immunization Practices. 2003. Using live, attenuated influenza vaccine for prevention and control of influenza: supplemental recommendations of the Advisory Committee on Immunization Practices (ACIP). MMWR Recomm Rep 52: 1-8.

Hobson D, Curry RL, Beare AS, Ward-Gardner A. 1972. The role of serum haemagglutination-inhibiting antibody in protection against challenge infection with influenza A2 and B viruses. J Hyg (Lond) 70: 767-777.

Hoffmann E, Mahmood K, Chen Z, Yang CF, Spaete J, Greenberg HB, Herlocher ML, Jin H, Kemble G. 2005. Multiple gene segments control the temperature sensitivity and attenuation phenotypes of $\mathrm{ca}$ B/Ann Arbor/1/66. J Virol 79: 11014-11021. doi:10.1128/JVI.79.17.1101411021.2005

Isakova-Sivak I, Grigorieva E, Rudenko L. 2020. Insights into current clinical research on the immunogenicity of live attenuated influenza vaccines. Expert Rev Vaccines 19: 43-55. doi:10.1080/14760584.2020.1711056

Jackson ML, Chung JR, Jackson LA, Phillips CH, Benoit J, Monto AS, Martin ET, Belongia EA, McLean HQ, Gaglani $\mathrm{M}$, et al. 2017. Influenza vaccine effectiveness in the United States during the 2015-2016 season. N Engl J Med 377: 534-543. doi:10.1056/NEJMoa1700153

Jegaskanda S, Mason RD, Andrews SF, Wheatley AK, Zhang R, Reynoso GV, Ambrozak DR, Santos CP, Luke CJ, Matsuoka Y, et al. 2018. Intranasal live influenza vaccine priming elicits localized B cell responses in mediastinal lymph nodes. J Virol 92: e01970-17. doi:10.1128/JVI .01970-17

Jin H, Subbarao K. 2015. Live attenuated influenza vaccine. Curr Top Microbiol Immunol 386: 181-204.

Jin H, Lu B, Zhou H, Ma C, Zhao J, Yang CF, Kemble G, Greenberg H. 2003. Multiple amino acid residues confer temperature sensitivity to human influenza virus vaccine strains (FluMist) derived from cold-adapted A/Ann Arbor/6/60. Virology 306: 18-24. doi:10.1016/S0042-6822 (02)00035-1

Karron RA, Callahan K, Luke C, Thumar B, McAuliffe J, Schappell E, Joseph T, Coelingh K, Jin H, Kemble G, et al. 2009a. A live attenuated H9N2 influenza vaccine is well tolerated and immunogenic in healthy adults. J Infect Dis 199: 711-716. doi:10.1086/596558

Karron RA, Talaat K, Luke C, Callahan K, Thumar B, Dilorenzo S, McAuliffe J, Schappell E, Suguitan A, Mills K, et al. 2009b. Evaluation of two live attenuated cold-adapted H5N1 influenza virus vaccines in healthy adults. Vaccine 27: 4953-4960. doi:10.1016/j.vaccine.2009.05.099

Kendal AP. 1997. Cold-adapted live attenuated influenza vaccines developed in Russia: can they contribute to meeting the needs for influenza control in other countries? Eur J Epidemiol 13: 591-609. doi:10.1023/A :1007327505862

Khurana S, Wu J, Dimitrova M, King LR, Manischewitz J, Graham BS, Ledgerwood JE, Golding H. 2013. DNA priming prior to inactivated influenza $\mathrm{A}(\mathrm{H} 5 \mathrm{~N} 1)$ vaccination expands the antibody epitope repertoire and increases affinity maturation in a boost-interval-dependent manner in adults. J Infect Dis 208: 413-417. doi:10 $.1093 /$ infdis/jit178

King JC Jr, Stoddard JJ, Gaglani MJ, Moore KA, Magder L, McClure E, Rubin JD, Englund JA, Neuzil K. 2006. Effectiveness of school-based influenza vaccination. $N$ Engl J Med 355: 2523-2532. doi:10.1056/NEJMoa055414

Kulkarni PS, Agarkhedkar S, Lalwani S, Bavdekar AR, Jog S, Raut SK, Parulekar V, Agarkhedkar SS, Palkar S, Mangrule S. 2014. Effectiveness of an Indian-made attenuated influenza $\mathrm{A}(\mathrm{H} 1 \mathrm{N1})$ pdm 2009 vaccine: a case control study. Hum Vaccin Immunother 10: 566-571. doi:10 $.4161 /$ hv. 27490

Kwong JC, Pereira JA, Quach S, Pellizzari R, Dusome E, Russell ML, Hamid JS, Feinberg Y, Winter AL, Gubbay JB, et al. 2015. Randomized evaluation of live attenuated vs. inactivated influenza vaccines in schools (RELATIVES) cluster randomized trial: pilot results from a household surveillance study to assess direct and indirect protection from influenza vaccination. Vaccine 33: 49104915. doi:10.1016/j.vaccine.2015.07.044

Ledgerwood JE, Wei CJ, Hu Z, Gordon IJ, Enama ME, Hendel CS, McTamney PM, Pearce MB, Yassine HM, Boyington JC, et al. 2011. DNA priming and influenza vaccine immunogenicity: two phase 1 open label randomised clinical trials. Lancet Infect Dis 11: 916-924. doi:10 .1016/S1473-3099(11)70240-7

Lewis KDC, Ortiz JR, Rahman MZ, Levine MZ, Rudenko L, Wright PF, Katz JM, Dally L, Rahman M, Isakova-Sivak I, et al. 2019. Immunogenicity and viral shedding of Russian-backbone, seasonal, trivalent, live, attenuated influenza vaccine in a phase II, randomized, placebocontrolled trial among preschool-aged children in urban Bangladesh. Clin Infect Dis 69: 777-785. doi:10.1093/cid/ ciy 1003

Li S, Liu C, Klimov A, Subbarao K, Perdue ML, Mo D, Ji Y, Woods L, Hietala S, Bryant M. 1999. Recombinant influenza A virus vaccines for the pathogenic human A/Hong Kong/97 (H5N1) viruses. J Infect Dis 179: 1132-1138. doi: $10.1086 / 314713$

Lim WW, Leung NHL, Sullivan SG, Tchetgen Tchetgen EJ, Cowling BJ. 2019. Distinguishing causation from correlation in the use of correlates of protection to evaluate and develop influenza vaccines. Am J Epidemiol doi:10.1093/ aje/kwz227

Lindsey BB, Jagne YJ, Armitage EP, Singanayagam A, Sallah HJ, Drammeh S, Senghore E, Mohammed NI, Jeffries D, Höschler K, et al. 2019. Effect of a Russian-backbone liveattenuated influenza vaccine with an updated pandemic H1N1 strain on shedding and immunogenicity among children in The Gambia: an open-label, observational, phase 4 study. Lancet Respir Med 7: 665-676. doi:10 .1016/S2213-2600(19)30086-4

Loeb M, Russell ML, Manning V, Fonseca K, Earn DJ, Horsman G, Chokani K, Vooght M, Babiuk L, Schwartz L, et al. 2016. Live attenuated versus inactivated influenza vaccine in Hutterite children: a cluster randomized blinded trial. Ann Intern Med 165: 617-624. doi:10.7326/M16-0513 
Maassab HF. 1967. Adaptation and growth characteristics of influenza virus at $25^{\circ} \mathrm{C}$. Nature 213: $612-614$. doi:10 $.1038 / 213612 \mathrm{a} 0$

Maassab HF. 1969. Biologic and immunologic characteristics of cold-adapted influenza virus. J Immunol 102: 728 732.

Maassab HF, Bryant ML. 1999. The development of live attenuated cold-adapted influenza virus vaccine for humans. Rev Med Virol 9: 237-244. doi:10.1002/(SICI) 1099-1654(199910/12)9:4<237::AID-RMV252>3.0.CO;2-G

Mallory RM, Malkin E, Ambrose CS, Bellamy T, Shi L, Yi T, Jones T, Kemble G, Dubovsky F. 2010. Safety and immunogenicity following administration of a live, attenuated monovalent $2009 \mathrm{H} 1 \mathrm{~N} 1$ influenza vaccine to children and adults in two randomized controlled trials. PLoS One 5: e13755. doi:10.1371/journal.pone.0013755

Mallory RM, Yu J, Kameo S, Tanaka M, Rito K, Itoh Y, Dubovsky F. 2018. The safety and efficacy of quadrivalent live attenuated influenza vaccine in Japanese children aged 2-18 years: results of two phase 3 studies. Influenza Other Respir Viruses 12: 438-445. doi:10.1111/irv.12555

Mallory RM, Bandell A, Ambrose CS, Yu J. 2020a. A systematic review and meta-analysis of the effectiveness of LAIV4 and IIV in children aged 6 months to 17 years during the 2016-2017 season. Vaccine doi:10.1016/j vaccine.2019.12.015

Mallory RM, Nyborg A, Kalyani RN, Yuan Y, Block SL, Dubovsky F. 2020b. A study to evaluate the immunogenicity and shedding of live attenuated influenza vaccine strains in children $24-<48$ months of age. Vaccine 38: 1001-1008. doi:10.1016/j.vaccine.2019.11.055

Matsuoka Y, Suguitan A Jr, Orandle M, Paskel M, Boonnak K, Gardner DJ, Feldmann F, Feldmann H, Marino M, Jin $\mathrm{H}$, et al. 2014. African green monkeys recapitulate the clinical experience with replication of live attenuated pandemic influenza virus vaccine candidates. $J$ Virol 88: 8139-8152. doi:10.1128/JVI.00425-14

McLean HQ, Caspard H, Griffin MR, Gaglani M, Peters TR, Poehling KA, Ambrose CS, Belongia EA. 2018. Association of prior vaccination with influenza vaccine effectiveness in children receiving live attenuated or inactivated vaccine. JAMA Netw Open 1: e183742. doi:10.1001/jama networkopen.2018.3742

Mendelman PM, Rappaport R, Cho I, Block S, Gruber W, August M, Dawson D, Cordova J, Kemble G, Mahmood $\mathrm{K}$, et al. 2004. Live attenuated influenza vaccine induces cross-reactive antibody responses in children against an A/Fujian/411/2002-like H3N2 antigenic variant strain. Pediatr Infect Dis J 23: 1053-1055. doi:10.1097/01.inf $.0000143643 .44463 . \mathrm{bl}$

Mills J, Chanock V, Chanock RM. 1971. Temperature-sensitive mutants of influenza virus. I. Behavior in tissue culture and in experimental animals. J Infect Dis 123: 145-157. doi:10.1093/infdis/123.2.145

Min JY, Vogel L, Matsuoka Y, Lu B, Swayne D, Jin H, Kemble G, Subbarao K. 2010. A live attenuated H7N7 candidate vaccine virus induces neutralizing antibody that confers protection from challenge in mice, ferrets, and monkeys. J Virol 84: 11950-11960. doi:10.1128/JVI.01305-10

Monto AS, Ohmit SE, Petrie JG, Johnson E, Truscon R, Teich E, Rotthoff J, Boulton M, Victor JC. 2009. Comparative efficacy of inactivated and live attenuated influenza vac- cines. N Engl J Med 361: 1260-1267. doi:10.1056/NEJ Moa0808652

Murphy BR. 1993. Use of live attenuated cold-adapted influenza A reassortant virus vaccines in infants, young adults, and elderly adults. Infect Dis Clin Pract 2: 174181. doi:10.1097/00019048-199305000-00003

Murphy BR, Coelingh K. 2002. Principles underlying the development and use of live attenuated cold-adapted influenza A and B virus vaccines. Viral Immunol 15: 295 323. doi:10.1089/08828240260066242

Nichol KL, Mendelman PM, Mallon KP, Jackson LA, Gorse GJ, Belshe RB, Glezen WP, Wittes J. 1999. Effectiveness of live, attenuated intranasal influenza virus vaccine in healthy, working adults: a randomized controlled trial. $J$ Am Med Assoc 282: 137-144. doi:10.1001/jama.282.2.137

Nohynek H, Baum U, Syrjänen R, Ikonen N, Sundman J, Jokinen J. 2016. Effectiveness of the live attenuated and the inactivated influenza vaccine in two-year-olds-a nationwide cohort study Finland, influenza season 2015/16. Euro Surveill 21: 30346. doi:10.2807/1560-7917.ES.2016 .21 .38 .30346

Ohmit SE, Victor JC, Rotthoff JR, Teich ER, Truscon RK, Baum LL, Rangarajan B, Newton DW, Boulton ML, Monto AS. 2006. Prevention of antigenically drifted influenza by inactivated and live attenuated vaccines. $N E n g l$ J Med 355: 2513-2522. doi:10.1056/NEJMoa061850

Ohmit SE, Victor JC, Teich ER, Truscon RK, Rotthoff JR, Newton DW, Campbell SA, Boulton ML, Monto AS 2008. Prevention of symptomatic seasonal influenza in $2005-2006$ by inactivated and live attenuated vaccines. $J$ Infect Dis 198: 312-317. doi:10.1086/589885

Ortiz JR, Goswami D, Lewis KD, Sharmeen AT, Ahmed M, Rahman M, Rahman MZ, Feser J, Neuzil KM, Brooks WA. 2015. Safety of Russian-backbone seasonal trivalent, live-attenuated influenza vaccine in a phase II randomized placebo-controlled clinical trial among children in urban Bangladesh. Vaccine 33: 3415-3421. doi:10.1016/j .vaccine.2015.04.048

Pebody R, Warburton F, Ellis J, Andrews N, Potts A, Cottrell S, Johnston J, Reynolds A, Gunson R, Thompson C, et al. 2016a. Effectiveness of seasonal influenza vaccine for adults and children in preventing laboratory-confirmed influenza in primary care in the United Kingdom: 2015/ 16 end-of-season results. Euro Surveill 21: 30348. doi: 10 2807/1560-7917.ES.2016.21.38.30348

Pebody R, Warburton F, Ellis J, Andrews N, Potts A, Cottrell S, Johnston J, Reynolds A, Gunson R, Thompson C, et al. 2016b. Effectiveness of seasonal influenza vaccine in preventing laboratory-confirmed influenza in primary care in the United Kingdom: 2015/16 mid-season results. Euro Surveill 21: 1-11 doi:10.2807/1560-7917.ES.2016.21.13 .30179

Pebody R, Sile B, Warburton F, Sinnathamby M, Tsang C, Zhao H, Ellis J, Andrews N. 2017a. Live attenuated influenza vaccine effectiveness against hospitalisation due to laboratory-confirmed influenza in children two to six years of age in England in the 2015/16 season. Euro Surveill 22: 30450. doi:10.2807/1560-7917.ES.2017.22.4 .30450

Pebody R, Warburton F, Ellis J, Andrews N, Potts A, Cottrell S, Reynolds A, Gunson R, Thompson C, Galiano M, et al. 2017b. End-of-season influenza vaccine effectiveness in 


\author{
K. Subbarao
}

adults and children, United Kingdom, 2016/17. Euro Surveill 22: 17-00306. doi:10.2807/1560-7917.ES.2017.22.44 .17-00306

Pebody R, McMenamin J, Nohynek H. 2018a. Live attenuated influenza vaccine (LAIV): recent effectiveness results from the USA and implications for LAIV programmes elsewhere. Arch Dis Child 103: 101-105. doi:10.1136/arch dischild-2016-312165

Pebody RG, Sinnathamby MA, Warburton F, Andrews N, Boddington NL, Zhao H, Yonova I, Ellis J, Tessier E, Donati M, et al. 2018b. Uptake and impact of vaccinating primary school-age children against influenza: experiences of a live attenuated influenza vaccine programme, England, 2015/16. Euro Surveill 23: 1700496. doi:10.2807/ 1560-7917.ES.2018.23.25.1700496

Pebody R, Djennad A, Ellis J, Andrews N, Marques DFP, Cottrell S, Reynolds AJ, Gunson R, Galiano M, Hoschler $\mathrm{K}$, et al. 2019. End of season influenza vaccine effectiveness in adults and children in the United Kingdom in 2017/18. Euro Surveill 24: 1800488. doi:10.2807/15607917.ES.2019.24.31.1800488

Pebody RG, Zhao H, Whitaker HJ, Ellis J, Donati M, Zambon M, Andrews N. 2020. Effectiveness of influenza vaccine in children in preventing influenza associated hospitalisation, 2018/19, England. Vaccine 38: 158-164. doi:10.1016/j.vaccine.2019.10.035

Peng Y, Wang B, Talaat K, Karron R, Powell TJ, Zeng H, Dong D, Luke CJ, McMichael A, Subbarao K, et al. 2015. Boosted influenza-specific $\mathrm{T}$ cell responses after H5N1 pandemic live attenuated influenza virus vaccination. Front Immunol 6: 287. doi:10.3389/fimmu.2015.00287

Penttinen PM, Friede MH. 2016. Decreased effectiveness of the influenza $\mathrm{A}(\mathrm{H} 1 \mathrm{~N} 1) \mathrm{pdm} 09$ strain in live attenuated influenza vaccines: an observational bias or a technical challenge? Euro Surveill 21: 30350. doi:10.2807/15607917.ES.2016.21.38.30350

Piedra PA, Gaglani MJ, Kozinetz CA, Herschler GB, Fewlass C, Harvey D, Zimmerman N, Glezen WP. 2007. Trivalent live attenuated intranasal influenza vaccine administered during the 2003-2004 influenza type A (H3N2) outbreak provided immediate, direct, and indirect protection in children. Pediatrics 120: e553-e564. doi:10.1542/peds .2006-2836

Pitisuttithum P, Boonnak K, Chamnanchanunt S, Puthavathana P, Luvira V, Lerdsamran H, Kaewkungwal J, Lawpoolsri S, Thanachartwet V, Silachamroon U, et al. 2017. Safety and immunogenicity of a live attenuated influenza H5 candidate vaccine strain A/17/turkey/Turkey/05/133 $\mathrm{H} 5 \mathrm{~N} 2$ and its priming effects for potential pre-pandemic use: a randomised, double-blind, placebo-controlled trial. Lancet Infect Dis 17: 833-842. doi:10.1016/S1473-3099 (17) $30240-2$

Plotkin SA. 2008. Vaccines: correlates of vaccine-induced immunity. Clin Infect Dis 47: 401-409. doi:10.1086/ 589862

Poehling KA, Caspard H, Peters TR, Belongia EA, Congeni B, Gaglani M, Griffin MR, Irving SA, Kavathekar PK, McLean HQ, et al. 2018. 2015-2016 Vaccine effectiveness of live attenuated and inactivated influenza vaccines in children in the United States. Clin Infect Dis 66: 665672. doi:10.1093/cid/cix869
Qin L, Gilbert PB, Corey L, McElrath MJ, Self SG. 2007. A framework for assessing immunological correlates of protection in vaccine trials. J Infect Dis 196: 1304-1312. doi: $10.1086 / 522428$

Rudenko L, Isakova-Sivak I. 2015. Pandemic preparedness with live attenuated influenza vaccines based on A/Lenin$\operatorname{grad} / 134 / 17 / 57$ master donor virus. Exp Rev Vaccines 14: 395-412. doi:10.1586/14760584.2015.979159

Rudenko LG, Slepushkin AN, Monto AS, Kendal AP, Grigorieva EP, Burtseva EP, Rekstin AR, Beljaev AL, Bragina VE, Cox N, et al. 1993. Efficacy of live attenuated and inactivated influenza vaccines in schoolchildren and their unvaccinated contacts in Novgorod, Russia. J Infect Dis 168: 881-887. doi:10.1093/infdis/168.4.881

Rudenko L, van den Bosch H, Kiseleva I, Mironov A, Naikhin A, Larionova N, Bushmenkov D. 2011. Live attenuated pandemic influenza vaccine: clinical studies on $\mathrm{A} / 17$ / California/2009/38 (H1N1) and licensing of the Russiandeveloped technology to WHO for pandemic influenza preparedness in developing countries. Vaccine 29(Suppl. 1): A40-A44. doi:10.1016/j.vaccine.2011.04.122

Rudraraju R, Mordant F, Subbarao K. 2019. How live attenuated vaccines can inform the development of broadly cross-protective influenza vaccines. J Infect Dis 219: S81-S87. doi:10.1093/infdis/jiy703

Singanayagam A, Zambon M, Lalvani A, Barclay W. 2018 Urgent challenges in implementing live attenuated influenza vaccine. Lancet Infect Dis 18: e25-e32. doi:10.1016/ S1473-3099(17)30360-2

Snyder MH, Betts RF, DeBorde D, Tierney EL, Clements ML, Herrington D, Sears SD, Dolin R, Maassab HF, Murphy BR. 1988. Four viral genes independently contribute to attenuation of live influenza A/Ann Arbor/6/60 (H2N2) cold-adapted reassortant virus vaccines. J Virol 62: 488-495. doi:10.1128/JVI.62.2.488-495.1988

Sobhanie M, Matsuoka Y, Jegaskanda S, Fitzgerald T, Mallory R, Chen Z, Luke C, Treanor J, Subbarao K. 2016. Evaluation of the safety and immunogenicity of a candidate pandemic live attenuated influenza vaccine (pLAIV) against influenza A(H7N9). J Infect Dis 213: 922-929. doi:10.1093/infdis/jiv526

Spring SB, Maassab HF, Kendal AP, Murphy BR, Chanock RM. 1977. Cold adapted variants of influenza A. II. Comparison of the genetic and biological properties of ts mutants and recombinants of the cold adapted A/AA/6/60 strain. Arch Virol 55: 233-246. doi:10.1007/BF01319909

Subbarao EK, Perkins M, Treanor JJ, Murphy BR. 1992. The attenuation phenotype conferred by the $\mathrm{M}$ gene of the influenza A/Ann Arbor/6/60 cold-adapted virus (H2N2) on the A/Korea/82 (H3N2) reassortant virus results from a gene constellation effect. Virus Res 25: 37-50. doi:10.1016/0168-1702(92)90098-T

Sullivan SG, Tchetgen Tchetgen EJ, Cowling BJ. 2016. Theoretical basis of the test-negative study design for assessment of influenza vaccine effectiveness. Am J Epidemiol 184: 345-353. doi:10.1093/aje/kww064

Talaat KR, Karron RA, Callahan KA, Luke CJ, DiLorenzo SC, Chen GL, Lamirande EW, Jin H, Coelingh KL, Murphy BR, et al. 2009. A live attenuated H7N3 influenza virus vaccine is well tolerated and immunogenic in a Phase I trial in healthy adults. Vaccine 27: 3744-3753. doi:10.1016/j.vaccine.2009.03.082 
Live Attenuated Cold-Adapted Influenza Vaccines

Talaat KR, Karron RA, Luke CJ, Thumar B, McMahon BA, Chen GL, Lamirande EW, Jin H, Coelingh KL, Kemble G, et al. 2011. An open label Phase I trial of a live attenuated H6N1 influenza virus vaccine in healthy adults. Vaccine 29: 3144-3148. doi:10.1016/j.vaccine.2011.02.043

Talaat KR, Karron RA, Liang PH, McMahon BA, Luke CJ, Thumar B, Chen GL, Min JY, Lamirande EW, Jin H, et al. 2013. An open-label phase I trial of a live attenuated $\mathrm{H} 2 \mathrm{~N} 2$ influenza virus vaccine in healthy adults. Influenza Other Respir Viruses 7: 66-73. doi:10.1111/j.1750-2659 .2012.00350.x

Talaat KR, Luke CJ, Khurana S, Manischewitz J, King LR, McMahon BA, Karron RA, Lewis KD, Qin J, Follmann DA, et al. 2014. A live attenuated influenza A(H5N1) vaccine induces long-term immunity in the absence of a primary antibody response. J Infect Dis 209: 1860-1869. doi:10.1093/infdis/jiu123

Uzicanin A, Thompson M, Smith P, Chaves SS, Foster L, Dube N, Graitcer S, Jackson R, Ferdinands J, Gargiullo P, et al. 2012. Effectiveness of 1 dose of influenza A (H1N1) 2009 monovalent vaccines in preventing reverse-transcription polymerase chain reaction-confirmed H1N1 infection among school-aged children in Maine. $J$ Infect Dis 206: 1059-1068. doi:10.1093/infdis/jis441
Vesikari T, Fleming DM, Aristegui JF, Vertruyen A, Ashkenazi S, Rappaport R, Skinner J, Saville MK, Gruber WC, Forrest BD, et al. 2006. Safety, efficacy, and effectiveness of cold-adapted influenza vaccine-trivalent against community-acquired, culture-confirmed influenza in young children attending day care. Pediatrics 118: 2298-2312. doi:10.1542/peds.2006-0725

Victor JC, Lewis KD, Diallo A, Niang MN, Diarra B, Dia N, Ortiz JR, Widdowson MA, Feser J, Hoagland R, et al. 2016. Efficacy of a Russian-backbone live attenuated influenza vaccine among children in Senegal: a randomised, double-blind, placebo-controlled trial. Lancet Glob Health 4: e955-e965. doi:10.1016/S2214-109X(16) 30201-7

Wang Z, Tobler S, Roayaei J, Eick A. 2009. Live attenuated or inactivated influenza vaccines and medical encounters for respiratory illnesses among US military personnel. $J \mathrm{Am}$ Med Assoc 301: 945-953. doi:10.1001/jama.2009.265

Wright PF, Hoen AG, Ilyushina NA, Brown EP, Ackerman ME, Wieland-Alter W, Connor RI, Jegaskanda S, Rosenberg-Hasson Y, Haynes BC, et al. 2016. Correlates of immunity to influenza as determined by challenge of children with live, attenuated influenza vaccine. Open Forum Infect Dis 3: ofw108. doi:10 $.1093 /$ ofid/ofw108 


\section{$\&_{\mathrm{CSH}}^{\infty} \&$ Cold Spring Harbor

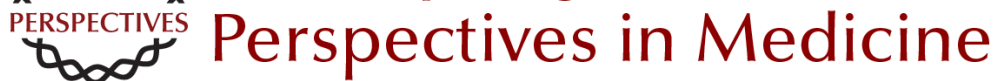

\section{Live Attenuated Cold-Adapted Influenza Vaccines}

Kanta Subbarao

Cold Spring Harb Perspect Med 2021; doi: 10.1101/cshperspect.a038653 originally published online April 6, 2020

\section{Subject Collection Influenza: The Cutting Edge}

\section{Emerging HxNy Influenza A Viruses William J. Liu, Yan Wu, Yuhai Bi, et al. \\ Equine Influenza \\ Thomas M. Chambers \\ Human Influenza Epidemiology \\ Sukhyun Ryu and Benjamin J. Cowling}

Host Cell Factors That Interact with Influenza

Virus Ribonucleoproteins

Ecco Staller and Wendy S. Barclay

Induction and Evasion of Type-I Interferon

Responses during Influenza A Virus Infection

Raquel Muñoz-Moreno, Carles Martínez-Romero and Adolfo García-Sastre

Structure and Function of Influenza Polymerase Joanna M. Wandzik, Tomas Kouba and Stephen Cusack

H7N9 Influenza Virus in China Chengjun Li and Hualan Chen

H5 Influenza Viruses in Egypt Rabeh El-Shesheny, Ahmed Kandeil, Ahmed Mostafa, et al.
Antivirals Targeting the Neuraminidase Larisa Gubareva and Teena Mohan

Accessory Gene Products of Influenza A Virus Rute M. Pinto, Samantha Lycett, Eleanor Gaunt, et al.

Influenza Immunization in the Context of

Preexisting Immunity Susanne L. Linderman, Ali H. Ellebedy, Carl Davis, et al.

Hemagglutinin Structure and Activities Steven J. Gamblin, Sébastien G. Vachieri, Xiaoli Xiong, et al.

Live Attenuated Cold-Adapted Influenza Vaccines Kanta Subbarao

Next-Generation Influenza Vaccines Masaru Kanekiyo and Barney S. Graham

\section{Selective Genome Packaging Mechanisms of Influenza A Viruses Takeshi Noda}

Systems Biological Analysis of Immune Response to Influenza Vaccination Mario Cortese, Amy C. Sherman, Nadine G. Rouphael, et al.

For additional articles in this collection, see http://perspectivesinmedicine.cshlp.org/cgi/collection/ 